\title{
Industrialização da celebridade
}

Camila Barros

INGLIS, F.

Uma breve história da celebridade.

Rio de Janeiro: Versal, 334 p., 2010.

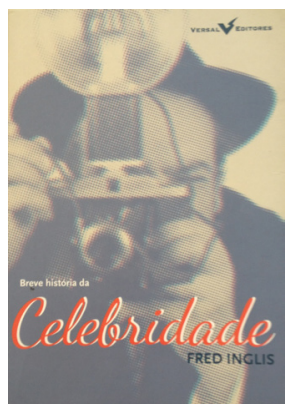

Resumo: Através de relatos descritivos acerca de personagens históricos, o texto percorre os 250 anos da história das celebridades. Entre o sociopolítico e a esfera do sentimento, a figura da celebridade nasce para uma identificação distante, que nos ensina como estar em sociedade. No decorrer dos capítulos, o autor demonstra como foi construída a "indústria da celebridade", como a fama deslocou-se do renome para o glamour e como esses atores sociais contribuem para a manutenção da ordem social.

Palavras-chave: celebridade; história; fama; indústria da celebridade.

Abstract: The industrialization of celebrity - Through descriptive narratives about historical characters, the text covers the 250 years of the brief history of celebrity. Between the sociopolitical and the sphere of sentiment, the figure of the celebrity emerges, offering a distant identification that teaches us how to live in society. Chapter by chapter, the author explains how the "celebrity industry" was built, how fame shifted from renown to glamour, and how these social actors contribute to maintain social order.

Keywords: celebrity; history; fame; celebrity industry. 
Entre ações e sentimentos, os personagens apresentados por Inglis, mais do que personificar figuras célebres, demonstram o caráter social dessa presença, que para um leitor despercebido, de leitura pré-concebida, pode se restringir à esfera do superficial. A "breve" história contada pelo autor demonstra que celebridades não são somente frutos de uma sociedade pautada pelo consumo - e que a necessidade de modelos é mesmo anterior à industrialização - mas que, associadas a dispositivos de consumo, as celebridades tornaram-se figuras notórias na engrenagem social. Essas trajetórias de vidas individuais funcionam, segundo o autor, como um adesivo que em um momento de fratura das esferas políticas evidencia a relação proposta entre a vida destes ilustres personagens e a conjuntura político-social de onde eles emergiram - dentre seres comuns - nos ensinando maneiras de estar no mundo e trabalhando para a manutenção dos valores estabelecidos.

No devir histórico, o significado "celebridade" foi associado a outras denominações. Entretanto, a substituição de termos sempre figurou entre sentidos de fama e glamour, com o passar do tempo se distanciando do sentido de renome e se aproximando do sentido hoje empregado, de celebração. A fama, em um contexto da máxima da individualização, passou a ser compreendida como recompensa, algumas vezes bastante efêmera. Essa gratificação social, a aclamação pública, deslocou o sentido da fama de devoção para celebração. Celebração esta que "gera através dos seus dramas, a estrutura de força com que as coisas são mantidas em seus devidos lugares" (p. 16).

Dada uma perspectiva histórica, o livro recua 250 anos até Londres de meados do século XVIII. A cultura urbana londrina pós-substituição da corte como centro da dinâmica social, ponto de partida escolhido pelo autor, apresentava as primeiras figuras públicas como autênticas celebridades. O teatro distorcia e amplificava a realidade social, exaltando personalidades e criando astros reconhecidos entre grupos sociais, muitas vezes à custa de escândalos. Outro aspecto importante para a consolidação de indivíduos celebráveis é o papel de formadores de opinião dos jornalistas literários, que agregavam valor à geração de falatórios sobre notícias e pessoas: tratava-se da fofoca que preservava a reputação de um pequeno grupo e excluía os demais.

Em meio à competição velada entre novos e velhos ricos, o emergente consumismo da Londres do séc. XVIII, somado ao crescimento da indústria da moda e ao advento dos jornais de grande circulação, com colunas cada vez mais modelizadoras de hábitos e comportamentos, criaram a fórmula necessária para a "industrialização da celebridade". O ver e ser visto encontrou seu espaço no lazer espetacular, na auto-exposição em pleasure gardens, invenção londrina que transformou Paris na cidade do consumo centrado na celebridade. A multidão chique desfilava pelos grands boulevards para observar as novidades em vitrines, mostrando-se com suas finas roupas, colocando a "aparência" como centro da fama. 
Chegando ao novo mundo, Nova York como grande centro financeiro, onde o poderio do dinheiro dispensava o renome dos velhos poderes aristocratas, as colunas de fofoca promoviam nomes e glamourizavam o dinheiro. Essa tríade de Londres, Paris e Nova York forneceu a estrutura que formou o que hoje compreendemos como celebridade.

Hollywood nasceu para esta celebração em um oportuno momento histórico em que o cenário desolador da Primeira Guerra terminou com líderes políticos, também construindo sua imagem de estrela. De políticos a produtos midiáticos, a capacidade de combinar distância e reconhecimento é compartilhada pelos diversos tipos de celebridades - como uma 'fluidez sobrenatural' elas oscilam entre a presença e a ausência (física) - e encontrou meio de rápida propagação através das novas mídias do começo do séc. XX e da ascensão da publicidade massiva. O privado vira pauta e argumento na construção desta figura distante, mas 'normal'. Nasce assim, a celebridade glamourizada, modelo que herdamos e exaltamos.

A instantaneidade provocada pela televisão e potencializada pela internet permitiu o compartilhamento do vivido na esfera privada. O distanciamento minimizado pela aparência promoveu a 'vida pública', que na perseguição pelo furo inevitável trouxe à tona sentimentos cruéis - que se tornaram justificados pela própria fórmula que sustenta, aquela da celebridade. Inglis nos diz que essas vidas célebres incorporam nossos valores e contradições em seu máximo. E nos perturba com a questão: já que a sociedade moderna é pautada por valores de consumo, "o que valemos para nós mesmos se prestamos tanta atenção às celebridades?" (p. 27).

Trazendo o texto de Inglis para o contexto nacional e aproximando com as figuras mais familiares - confesso que o desconhecimento de parte das figuras citadas fracionou a leitura - o que percebemos é que este é um fenômeno global, em que a celebridade pode ser vista como um sintoma desta sociedade de discursos fluidos e frágeis que necessitam de muitos remendos (Žižek, 1996). Como disse Inglis, ela funciona como "cola", em que o adesivo encobre e reconecta trechos desse discurso ordenador maior.

Também fragmentado, o sentimento aparece sempre encobrindo os porquês desta exaltação, por vezes sem sentido. O pastor que não crê, o político conhecido porque namora a apresentadora, a garota que ficou famosa por tirar a roupa em um aeroporto [...] celebridades parasitárias de um tempo cínico (Safatle, 2008). O renome de outrora foi substituído por um vazio que clama por preenchimento. Essa tensão é espaço fértil para a promoção de regimes áuricos de visibilidade e para a construção do "eu célebre".

Dialogando com um texto que outrora li a respeito de um assalto sofrido por um ator nacional, o ensaísta Francisco Bosco propôs que a fama vazia da sociedade do espetáculo resulta da reprodução e da repetição da imagem. Como uma fama tautológica, alguém é famoso porque é famoso. A pergunta que Inglis nos faz no decorrer do livro é: o que as celebridades nos deram em troca? Aparece também como questionamento para Bosco: 
Mas o que oferece às pessoas a maioria das celebridades midiáticas de hoje? Nada? Não, pior: oferecem seu gozo a uma testemunha masoquista, humilhada, e em nada ajudam as pessoas a desenvolver suas potências, criar um quadro de valores com alguma autonomia, tornar-se críticas, arriscar formas de vida experimentais, crescer, brilhar, emancipar-se (BOSCO, 2010).

Esse sentimento de angústia revelado na busca do outro como modelo ideal, jamais será alcançado. São modelos descartáveis e parasitários, que crescem à sombra de sonhos irreais da estação, modelos de vidas para consumo, que fazem a engrenagem funcionar e limitam o potencial criativo de cada ser singular (Bauman, 2008). Afinal, "histórias sobre celebridades devem prender nossa atenção, pois desagrado entediado não é admissível, e as celebridades sempre têm o que nos dizer sobre o sentido de nossas vidas" (p. 121).

Camila Barros é doutoranda em Comunicação e Semiótica na PUC-SP e bolsista do CNPq.

camilabfb@gmail.com

\section{Referências}

BAUMAN, Z. Vida para consumo. Rio de janeiro, Zahar, 2008.

BOSCO, F. (2010) Celebridade e Barbárie. In: Revista Cult, 147, agosto de 2010. Disponível em: <http://revistacult.uol.com.br/home/2010/06/celebridade-e-barbarie>. Acesso em: 03 mar. 2013.

INGLIS, F. Uma breve história da celebridade. Rio de Janeiro, Versal, 2010.

SAFATLE, V. P. Cinismo e falência da crítica. São Paulo: Boitempo, 2008.

ŽIŽEK, S. (1996) Como Marx inventou o sintoma? In: Um mapa da ideologia. Rio de Janeiro: Contraponto, 1996. 